\title{
Erratum to: Jennifer Y. J. Hsu and Reza Hasmath, The Chinese Corporatist State: Adaption, Survival and Resistance
}

\section{(London and New York: Routledge, 2013), 150pp. \$114 Hardcover}

\section{Baogang Guo}

\section{Erratum to: J OF CHIN POLIT SCI \\ DOI 10.1007/s11366-013-9263-1}

The original version of the article unfortunately contained mistakes. There were two slight spelling errors. The correct information are given below.

On page 2, first line, "Gerry Group's" should be "Gerry Groot's" and page 2, last paragraph, first line, "Reze Hasmath" should be "Reza Hasmath".

The online version of the original article can be found at http://dx.doi.org/10.1007/s11366-013-9263-1.

B. Guo

Dalton State College, 650 College Drive, Dalton, GA 30720, USA

Present Address:

B. Guo $(\square)$

22745 Post Oak Tritt Road, Marietta, GA 30062, USA

e-mail: bguo@daltonstate.edu 